\title{
Does The Presence Of Independent Directors Influence Accruals Management?
}

Ramzi Benkraiem, GSCM - Montpellier Business School - France

\begin{abstract}
Recent debates about the functioning of boards of directors have focused on the disciplinary role of independent directors (ID). Evaluating the effectiveness of this role is an interesting empirical question. This study seeks to examine the influence of these directors and two other corporate governance mechanisms, namely the audit quality and the ownership structure, on earnings management as measured by working capital discretionary accruals (WCDAC). The analysis, conducted over a period of 4 years from 2001 to 2004, is based on a sample of 239 different French companies listed on the Paris stock exchange. The findings show that the presence of ID can moderate the management of WCDAC. This role appears to be more effective when these ID make up at least one third of the members of boards of directors, as recommended by the Vienot 1999 report. The Big 4 auditors can also limit this discretionary adjustment. However, no statistically significant relationship was observed between dispersion vs. concentration of ownership structure and WCDAC. This study adds to the limited research into the relationship between corporate governance and earnings management in France. It also gives empirical evidence on the effectiveness of the Viénot 1999 report's recommendations. Thus, it should be of interest to academics as well as regulators in preparing and amending corporate governance laws.
\end{abstract}

Keywords: Independent directors, audit quality, ownership structure, earnings management, working capital discretionary accruals.

\section{INTRODUCTION}

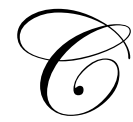

orporate managers can use the managerial latitude to maximize their own interests, sometimes at the expense of shareholders, creditors and other stakeholders' wealth. From an accounting standpoint, they can thus take advantage of the flexibility offered by the standards and engage in activities known as "earnings management" so as to modulate the financial information to be disclosed. This modulation consists concretely in opting for accounting decisions that individually comply with the legal framework but are globally oriented towards the fulfillment of specific self-serving objectives. A monitoring of corporate managers may then be necessary in order to limit the scope of these practices. In this framework, independent directors (subsequently referred to as ID), key actors of corporate governance, have a decisive role to play. The markets increasingly look to them to help guarantee reliable and accurate financial information (Stolowy and Jeanjean, 2006; Perta, 2007). From a disciplinary standpoint, these ID are regarded as an important source of the effectiveness of boards of directors (Fama, 1981, Fama and Jensen, 1983; Beasly, 1996).

The main objective of this paper is to study the relationship between the presence of ID and the managerial discretion exercised specifically at the accounting level. More specifically, it seeks to answer the question: can ID influence and limit earnings management practices in France?

This question has been brought to the fore by recent financial scandals and made crucial by the changes in the French institutional context. The need to guarantee quality accounting information is now an increasingly important issue for the firm's various partners. Accordingly, it seems important to know whether ID play an effective role at this level. 
This paper makes an interesting contribution by making it possible to evaluate empirically the effectiveness of this role. It adds to the limited research into the relationship between corporate governance and earnings management in France. It also gives empirical evidence on the effectiveness of the Viénot 1999 report's recommendations [Viénot report promotes non-binding corporate governance principles dealing with director compensation and independence. While this report is non-binding, French listed companies are strongly invited to comply with it]. Thus, it should be of interest to academics as well as regulators in preparing and amending corporate governance laws.

The remainder of this paper is organized as follows: section 2 presents the theoretical framework and formulates the hypotheses, section 3 describes the methodology, Section 4 presents and discusses the results and section 5 serves as the conclusion.

\section{THEORETICAL FRAMEWORK AND HYPOTHESES DEVELOPMENT}

\subsection{Earnings management}

According to Dechow and Skinner (2000), earnings management practices are directly linked to the accrual based accounting. In fact, the choice of the moment when revenues and charges are recorded creates a variation that constitutes the difference between cash vs. accrual based accounting. In the long run, this variation will tend to disappear, since earnings must normally tend towards the cash flows. In the short term, however, it is potentially adjustable (Dechow and Dichev, 2002). Earnings management represents a way of manipulating this variation. This manipulation comprises a set of accounting choices whose objective is to modify firms' reported earnings. It is carried out in compliance with prevailing accounting standards. Researchers in accounting and finance have devoted considerable energy to studying this phenomenon (for a review of this literature, see Stolowy and Breton, 2004). From an academic point of view, several methods have been developed for the purposes of analysis and have become increasingly refined over time. In this domain and since the study of Healy (1985), most research has sought to study earnings management on the basis of "accruals". This measure includes all the adjustments that make it possible to move from cash to accrual based accounting. As Cormier et al. (1998, p. 27) emphasize, "such an approach seems logical since accruals represent a global measure of the company's accounting disclosure strategy and are therefore more likely to reflect a strategic decision of corporate managers than simply studying a particular accounting method".

\subsection{Independent directors and earnings management}

The roles assigned in a general way to boards of directors and specifically to ID can vary according to the theories of corporate governance. Thus, Charreaux (2004) distinguishes two main categories of theories in this area: contractual and strategic theories. Contractual theories are aimed at disciplining corporate managers and protecting shareholders' interests, whereas strategic theories aim essentially at wealth creation, particularly through the creation of knowledge, skills, etc. It should be noted that this paper subscribes to the former category of theories. One of the most important functions assigned to the board of directors in France is that of overseeing corporate managers. Indeed, Article L. 225-35 of the French Commercial Code stipulates that "the board of directors determines the orientations of the company's business activity and oversees their implementation. It addresses any question relating to the smooth operation of the company and decides through its deliberations on the matters that concern it [...]. The board of directors carries out the appropriate checks and verifications. The Chief Executive of the company is required to supply each director with all documents and information necessary for the fulfillment of his duties". As outlined above, one of the decisive sources of effectiveness of these boards is the presence of ID (Fama, 1981; Fama and Jensen, 1983; Beasly, 1996). According to the Bouton 2002 report (p. 9) [Bouton is a report published in France in reaction to the Enron and Vivendi Universal scandals. It extends the Viénot report and promotes stricter nonbinding principles regarding director's independence, financial information, etc.], a director is defined as independent "when he has no relationship of any kind whatsoever with the company, its group or its management that could compromise the exercise of his freedom of judgment". At least two reasons can motivate ID to fulfill their role efficiently. First, ID are often recruited on the basis of their reputation on the director market. Their career development seems to be directly associated with their reputation. Secondly, the absence of subordination to corporate managers makes it easier for them to openly oppose these managers' decisions. The presence of ID (i.e. 
directors without any subordinate relationship with the company) can limit earnings management. Several previous papers, mainly Anglo-Saxons, have tended to show that discretionary accruals are negatively associated with ID (Peasnell et al., 2000; Klein, 2002; Xie et al., 2003; Benkel et al., 2006). This leads to the first hypothesis:

H1 - Independent directors will be negatively associated with earnings management.

\subsection{Other corporate governance mechanisms and earnings management}

As well as the presence of ID, other corporate governance mechanisms can limit earnings management behavior. Two additional mechanisms can be highlighted: the audit quality and the ownership structure.

The audit quality can influence the opportunistic accounting choices of corporate managers. DeAngelo (1981) shows analytically that "big" auditing firms are more motivated than "small" ones to provide high-quality controls on accounts.

Two arguments can support this thesis:

(1) The loss of reputation is more important for big auditors in the event of a problem arising from certification.

(2) Big auditors are usually wealthier and thus more liable to be sued for damages in the event of malpractice.

From an empirical standpoint, Francis and Krishnan (1999) find that companies audited by the Big 6 auditors use less discretionary accruals than others to adjust reported earnings. Kim et al. (2003) confirm this negative relationship. Furthermore, they add that the Big auditors exercise more effective control when corporate managers are motivated to manipulate earnings upwards. In the Swiss context, Cormier et al. (1998) also show that the Big 6 reduce recourse to total and discretionary accruals. In France, Jeanjean (2001) confirms this association. Nevertheless, he highlights a smaller moderating effect (in terms of extent and statistical significance) than that found by the other Anglo-Saxon cited research. Overall, the quality of external audit seems to play an effective role in limiting the extent of discretionary accruals. This leads to the second hypothesis:

H2 - Big 4 auditors will be negatively associated with earnings management.

The ownership structure can also influence earnings management practices. Several researchers suggest that the accounting behavior of controlled companies is less active than that of managerial firms. According to Jeanjean (2001), it is possible to identify two dividing lines with regard to ownership structure:

(1) A first distinction between firms owned by their corporate managers, vs. other companies.

(2) A second distinction between companies with concentrated vs. diffused ownership structure.

Some empirical studies tend to confirm the influence of a large stockholder on firms' accounting policy. Thus, based on a sample of firms that made an initial public offering in Quebec, Cormier and Magnan (1995) find that forecast-issuing companies whose corporate managers maintain a high degree of ownership manipulate their earnings less than firms where corporate managers retain only a low level of ownership. Coherently, in the French context, Cormier and Martinez (2006) show that the opportunistic accounting behaviour of managerial firms (dispersed ownership structure, i.e. absence of a large blockholder) is more active than that in controlled companies. This leads to the third hypothesis:

H3 - Dispersed ownership structure will be positively associated with earnings management.

\section{METHODOLOGY}

To study the influence of ID and other corporate governance mechanisms on the managerial discretion carried out to adjust reported earnings, we use discretionary accruals as a proxy for earnings management. Several estimation models are put forward by the literature. We focus in this study on working-capital (i.e. short-term) 
discretionary accruals. The contribution of this approach in detecting earnings management has been highlighted by several papers. In this regard, authors such as Young (1999), Peasnell et al. (2000) and Xie et al. (2003) emphasize that the discretionary adjustment of short-term items is easier for corporate managers than long-term items. In their view, managing long-term items generally requires modifying the depreciation policy, which is more visible for external users of the financial information.

In what follows, the estimation of these accruals, the specifications of the empirical model and the sample are presented, respectively.

\subsection{Estimation of working capital discretionary accruals}

For the purposes of estimating working capital discretionary accruals, the first task is to calculate the total working capital accruals as follows (Peasnell et al., 2000; Xie et al., 2003):

$\mathrm{TWCAC}_{\mathrm{it}}=\left(\triangle \mathrm{CA}_{\mathrm{it}}-\triangle \mathrm{Cash}_{\mathrm{it}}\right)-\left(\triangle \mathrm{CL}_{\mathrm{it}}-\triangle \mathrm{STD}_{\mathrm{it}}\right)$

Where for firm $i$ in year $t: \triangle \mathrm{CA}_{\mathrm{it}}$ is the change in current assets; $\triangle \mathrm{Cash}_{\mathrm{it}}$ is the change in cash and cash equivalents; $\triangle \mathrm{CL}$ it is the change in current liabilities and $\triangle \mathrm{STD}_{\mathrm{it}}$ is the change in long-term debt included in current liabilities.

The total working capital accruals (TWCAC) calculated includes normal and abnormal parts. Only the abnormal part is assumed to reflect subjective accounting choices made by corporate managers. Using industry and fiscal year combination, working capital discretionary accruals (WCDAC) are obtained by calculating the difference between total and non-discretionary working capital accruals:

$\mathrm{WCDAC}_{\mathrm{it}} / \mathrm{A}_{\mathrm{it}-1}=\left(\mathrm{TWCAC}_{\mathrm{it}} / \mathrm{A}_{\mathrm{it}-1}\right)-\left[\beta_{0}\left(1 / \mathrm{A}_{\mathrm{it}-1}\right)+\beta_{1}\left(\left(\triangle \mathrm{REV}_{\mathrm{it}}-\triangle \mathrm{AR}_{\mathrm{it}}\right) / \mathrm{A}_{\mathrm{it}-1}\right)\right]$

Where for firm $i$ in year $t: A_{\mathrm{it}-1}$ is the lagged total assets; $\triangle \mathrm{REV}_{\mathrm{it}}$ is the change in sales revenues and $\triangle \mathrm{AR}_{\mathrm{it}}$ is the change in account receivables.

\subsection{Specifications of the empirical model}

To test the hypotheses already formulated, the empirical model set out below is posited. As regards ID variable, it seems useful to turn first of all to an important source of "good practices" of corporate governance in France. The unique text called "collective, 2003", combining the Viénot and Bouton reports can serve as a particularly judicious source. The deployed conception of independence tends increasingly to be based upon the main criterion of the absence of any link of direct or indirect interest between the director and the company. This criterion seems to be aimed at enabling the director to exercise his duties objectively, without any dependence upon corporate managers. In the strict sense, it does not consider all external directors as automatically independent. In other words, a director who is defined as external because he does not have any operating responsibilities may have a connecting interest with the firm and as a result not be considered independent. French companies often invoke the conditions set out by these reports in declaring the independence of their directors. This research is therefore based upon the information given in the companies' annual reports. Only the directors described as such in these reports are here considered independent. This choice may lead to an underestimation of the presence of ID (i.e. ID not mentioned in the annual reports). Nevertheless, it has the advantage of taking into account the contextual specificities and thus bringing methodological rigor into the analysis. Two dichotomous variables are then used to assess the influence of ID. These variables respectively take the value 1 in the case of the presence of ID and in the case of boards comprising at least one third of ID, as recommended by the Viénot 1999 report.

To assess the audit quality, in accordance with the existing literature (DeAngelo, 1981; Francis and Krishnan, 1999, Chung, Firth and Kim, 2005), we distinguish between certifiers belonging to the 4 Big auditors and the others. We thus establish a dichotomous variable which takes the value 1 when the company's accounting records are certified by a Big 4 . 
The ownership structure variable is introduced because previous studies suggest that the opportunistic accounting behavior of managerial firms (i.e. with diffused ownership structure) is more active than that of controlled firms (Cormier and Magnan, 1995; Cormier and Martinez, 2006). A dichotomous variable, representing a diffused ownership structure, is then used. Based on the IAS no. 28 , the $20 \%$ threshold, corresponding to the concept of significant influence, is adopted to signal that the capital is dispersed. The designated variable takes the value 1 when no blockholder holds more than $20 \%$ of the total ordinary shares outstanding.

The empirical model presented below takes into consideration different control variables because the corporate governance variables are not the only ones that could potentially influence the opportunistic adjustment of WCDAC. These variables refer to the company size, its debt (Watts and Zimmerman, 1986), its relative earnings performance (Kim et al., 2003; Chung et al., 2005) and its lagged WCDAC (Sloan, 1996; Koh, 2003; Grace and Koh, 2005).

$$
\begin{aligned}
\text { WCDAC }_{\mathrm{it}} & =\delta_{0}+\delta_{1} \mathrm{PID}_{\mathrm{it}}\left[\text { or IDT }_{\mathrm{it}}\right]+\delta_{2} \mathrm{BA}_{\mathrm{it}}+\delta_{3} \mathrm{DOS}_{\mathrm{it}}+\delta_{4} \mathrm{SIZE}_{\mathrm{it}}+\delta_{5} \mathrm{DEBT}_{\mathrm{it}}+\delta_{6} \mathrm{REP}_{\mathrm{it}}+\delta_{7} \mathrm{LWCDAC}_{\mathrm{it}} \\
& +\sum_{\mathrm{k}=2001}^{2003} \beta_{\mathrm{K}} \text { Year k }+\varepsilon_{\mathrm{it}}
\end{aligned}
$$

Where for firm $i$ in year $t$ : PID is a dummy variable, 1 if board of directors comprises ID and 0 otherwise; IDT is a dummy variable, 1 if board of directors comprises at least one third of ID and 0 otherwise; BA is a dummy variable, 1 if the auditor is a Big 4 and 0 otherwise; DOS is a dummy variable, 1 if no stockholder holds more than $20 \%$ of the total ordinary shares outstanding; SIZE is the logarithm of market capitalization; DEBT is total debts divided by total assets; REP is a dummy variable, 1 if the operating cash flow for a firm is below the industry annual median of operating cash flows [poor performance] and 0 otherwise; LWCDAC are the lagged WCDAC and Year K is a dummy variable, 1 if the year is $\mathrm{K}$ and 0 otherwise.

\subsection{Sample}

The accounting and financial data are from AMADEUS. This database comprises the consolidated financial statements of 629 French companies listed on the Paris stock exchange. The initial sample is composed of all the French companies available over the period 2001-2004. Financial and assimilated companies are excluded because of their specific accounting rules. Real estate and holding companies are also excluded. This because the crosssectional intra-industry estimation model of WCDAC is based on the assumption of firms' homogeneity in the same industry (Koh, 2003). These companies operate in various industries and exploit diversified resources. They therefore clearly violate this assumption. The other independent variables are collected from the annual reports. Taking into account the analyses to be conducted, the information required for calculation of the WCDAC had to be available for at least 2 consecutive years. Companies for which information was missing are therefore excluded. To ensure the estimation efficiency of discretionary accruals, industries for which observations were less than 10 per year are therefore excluded. The final sample is made up of 239 different French companies listed on the Paris stock exchange.

\section{RESULTS}

At this stage, the descriptive statistics of our different variables, the Pearson correlation matrix and the regression results of Eq. 3 will be presented, respectively.

\subsection{Descriptive statistics}

Table 1 presents the descriptive statistics of the variables used. The WCDAC are negative and amount on average to $-0.6 \%$. These WCDAC amount to $-5.75 \%$ for the first quartile and $5.5 \%$ for the third quartile of firms. This shows that some corporate managers adjust their earnings downwards while others manage them upwards. The PID is on average $61.3 \%$. Since we are dealing with a dichotomous variable, this mean indicates a frequency. More than $61 \%$ of the companies in our sample mention in their annual reports the presence of ID in their boards of directors. The IDT amounts on average to $40.5 \%$. More than $40 \%$ of the companies expressly state in their annual 
reports that the boards of directors include at least one third of ID. For the other governance variables, this same table shows that almost half of the companies have financial statements certified by the Big 4 . It also indicates that more than $16 \%$ of these companies have a diffused ownership structure.

In addition, the variable SIZE calculated from the market capitalization amounts to 3.8 on average and its standard deviation is 1.796 . It shows the highest "variability". DEBT is equal to 0.056 , which means that the companies in our sample have debt amounting on average to $5.56 \%$ of their total assets. Half of the companies have the operating cash flow lower than the industry annual median of operating cash flows. Finally, the LWCDAC are on average equal to $0.1 \%$. Their values observed for each quartile of firms are almost the same as those of WCDAC for the current year.

Table 1

Descriptive statistics for dependent and independent variables

\begin{tabular}{lccccc}
\hline & Mean & St. Dev. & \multicolumn{2}{c}{ Quartiles } \\
\cline { 4 - 6 } & & & 25 & 50 & 75 \\
\hline WCDAC & -0.006 & 0.121 & -0.058 & 0 & 0.055 \\
PID & 0.613 & 0.464 & 0 & 0 & 1 \\
IDT & 0.405 & 0.404 & 0 & 0 & 1 \\
BA & 0.480 & 0.500 & 0 & 0 & 1 \\
DOS & 0.164 & 0.370 & 2.526 & 3.501 & 1 \\
SIZE & 3.813 & 1.796 & 0.012 & 0.026 & 0.062 \\
DEBT & 0.056 & 0.078 & 0 & 1 & 1 \\
REP & 0.502 & 0.500 & -0.060 & -0.004 & 0.055 \\
LWCDAC & 0.001 & 0.175 & 0.966 \\
\hline
\end{tabular}

Where for firm $i$ in year $t$ : WCDAC are the working capital discretionary accruals computed using Eq. 2; PID is a dummy variable, 1 if board of directors comprises ID and 0 otherwise; IDT is a dummy variable, 1 if board of directors comprises at least one third of ID and 0 otherwise; BA is a dummy variable, 1 if the auditor is a Big 4 and 0 otherwise; DOS is a dummy variable, 1 if no stockholder holds more than $20 \%$ of the total ordinary shares outstanding; SIZE is the logarithm of market capitalization; DEBT is total debts divided by total assets; REP is a dummy variable, 1 if the operating cash flow for a firm is below the industry annual median of operating cash flows [poor performance] and 0 otherwise and LWCDAC are the lagged WCDAC.

Table 2

Pearson correlation matrix

\begin{tabular}{|c|c|c|c|c|c|c|c|c|}
\hline & PID & IDT & BA & DOS & SIZE & DEBT & REP & LWCDAC \\
\hline \multirow[t]{2}{*}{ PID } & 1 & 0.751 & 0.280 & 0.035 & 0.305 & 0.133 & 0.003 & 0.033 \\
\hline & & $(0.000)$ & $(0.000)$ & $(0.308)$ & $(0.000)$ & $(0.000)$ & $(0.937)$ & $(0.376)$ \\
\hline \multirow[t]{2}{*}{ IDT } & & 1 & 0.220 & 0.064 & 0.215 & 0.070 & 0.001 & 0.045 \\
\hline & & & $(0.000)$ & $(0.065)$ & $(0.000)$ & $(0.044)$ & $(0.974)$ & $(0.230)$ \\
\hline \multirow[t]{2}{*}{ BA } & & & 1 & 0.034 & 0.270 & 0.076 & 0.009 & 0.041 \\
\hline & & & & $(0.324)$ & $(0.000)$ & $(0.029)$ & $(0.805)$ & $(0.275)$ \\
\hline \multirow[t]{2}{*}{ DOS } & & & & 1 & 0.021 & 0.073 & 0.090 & 0.015 \\
\hline & & & & & $(0.543)$ & $(0.037)$ & $(0.010)$ & $(0.685)$ \\
\hline \multirow[t]{2}{*}{ SIZE } & & & & & 1 & 0.170 & -0.183 & 0.132 \\
\hline & & & & & & $(0.000)$ & $(0.000)$ & $(0.000)$ \\
\hline \multirow[t]{2}{*}{ DEBT } & & & & & & 1 & 0.072 & -0.011 \\
\hline & & & & & & & $(0.037)$ & $(0.766)$ \\
\hline \multirow[t]{2}{*}{ REP } & & & & & & & 1 & -0.170 \\
\hline & & & & & & & & $(0.000)$ \\
\hline LWCDAC & & & & & & & & 1 \\
\hline
\end{tabular}

Where for firm $i$ in year $t$ : PID is a dummy variable, 1 if board of directors comprises ID and 0 otherwise; IDT is a dummy variable, 1 if board of directors comprises at least one third of ID and 0 otherwise; BA is a dummy variable, 1 if the auditor is a Big 4 and 0 otherwise; DOS is a dummy variable, 1 if no stockholder holds more than $20 \%$ of the total ordinary shares outstanding; SIZE is the logarithm of market capitalization; DEBT is total debts divided by total assets; REP is a dummy variable, 1 if the operating cash flow for a firm is below the industry annual median of operating cash flows and 0 otherwise; LWCDAC are the lagged WCDAC. 
Table 3

The regression results of WCDAC on various variables

\begin{tabular}{|c|c|c|c|c|c|c|c|c|c|c|c|}
\hline \multicolumn{12}{|c|}{ 1st specification: } \\
\hline \multicolumn{12}{|c|}{$\mathrm{WCDAC}_{\mathrm{it}}=\delta_{0}+\delta_{1} \mathrm{PID}_{\mathrm{it}}+\delta_{2} \mathrm{BA}_{\mathrm{it}}+\delta_{3} \mathrm{DOS}_{\mathrm{it}}+\delta_{4} \mathrm{SIZE}_{\mathrm{it}}+\delta_{5} \mathrm{DEBT}_{\mathrm{it}}+\delta_{6} \mathrm{REP}_{\mathrm{it}}+\delta_{7} \mathrm{LWCDAC}_{\mathrm{it}}+\sum_{\mathrm{k}=2001}^{2003} \beta_{\mathrm{K}}$ Year k$+\varepsilon_{\mathrm{it}}$} \\
\hline & $\delta_{0}$ & $\delta_{1}$ & $\delta_{2}$ & $\delta_{3}$ & $\delta_{4}$ & $\delta_{5}$ & $\delta_{6}$ & $\delta_{7}$ & $\delta_{8}$ & $\delta_{9}$ & $\delta_{10}$ \\
\hline Coef. & -0.080 & -0.017 & -0.021 & -0.012 & 0.018 & -0.105 & 0.074 & -0.067 & -0.020 & -0.008 & -0.007 \\
\hline t stat. & -5.926 & -1.894 & -2.486 & -1.173 & 7.371 & -2.025 & 9.082 & -2.730 & -1.771 & -0.721 & -0.583 \\
\hline$P$ value & 0.000 & 0.059 & 0.013 & 0.241 & 0.000 & 0.043 & 0.000 & 0.007 & 0.077 & 0.471 & 0.560 \\
\hline Adj. R2 & \multicolumn{11}{|c|}{$12.8 \%(\mathrm{P}$ value of $\mathrm{F}$ stat $<1 \%)$} \\
\hline \multicolumn{12}{|c|}{ 2nd specification: } \\
\hline \multicolumn{12}{|c|}{$\mathrm{WCDAC}_{\mathrm{it}}=\delta_{0}+\delta_{1} \mathrm{IDT}_{\mathrm{it}}+\delta_{2} \mathrm{BA}_{\mathrm{it}}+\delta_{3} \mathrm{DOS}_{\mathrm{it}}+\delta_{4} \mathrm{SIZE}_{\mathrm{it}}+\delta_{5} \mathrm{DEBT}_{\mathrm{it}}+\delta_{6} \mathrm{REP}_{\mathrm{it}}+\delta_{7} \mathrm{LWCDAC}_{\mathrm{it}}+\sum_{\mathrm{k}=2001}^{2003} \beta_{\mathrm{K}} \mathrm{Year} \mathrm{k}+\varepsilon_{\mathrm{it}}$} \\
\hline & $\delta_{0}$ & $\delta_{1}$ & $\delta_{2}$ & $\delta_{3}$ & $\delta_{4}$ & $\delta_{5}$ & $\delta_{6}$ & $\delta_{7}$ & $\delta_{8}$ & $\delta_{9}$ & $\delta_{10}$ \\
\hline Coef. & -0.079 & -0.023 & -0.021 & -0.012 & 0.018 & -0.109 & 0.074 & -0.066 & -0.020 & -0.008 & -0.007 \\
\hline t stat. & -5.891 & -2.278 & -2.533 & -1.084 & 7.399 & -2.123 & 9.080 & -2.689 & -1.794 & -0.724 & -0.603 \\
\hline $\mathrm{P}$ value & 0.000 & 0.023 & 0.012 & 0.279 & 0.000 & 0.034 & 0.000 & 0.007 & 0.073 & 0.469 & 0.547 \\
\hline Adj. R2 & $13 \%(\mathrm{P} v a$ & F stat $<$ & & & & & & & & & \\
\hline
\end{tabular}

Where for firm $i$ in year $t$ : WCDAC are the working capital discretionary accruals computed using Eq. 2; PID is a dummy variable, 1 if board of directors comprises ID and 0 otherwise; IDT is a dummy variable, 1 if board of directors comprises at least one third of ID and 0 otherwise; BA is a dummy variable, 1 if the auditor is a Big 4 and 0 otherwise; DOS is a dummy variable, 1 if no stockholder holds more than $20 \%$ of the total ordinary shares outstanding; SIZE is the logarithm of market capitalization; DEBT is total debts divided by total assets; REP is a dummy variable, 1 if the operating cash flow for a firm is below the industry annual median of operating cash flows [poor performance] and 0 otherwise; LWCDAC are the lagged WCDAC and Year K is a dummy variable, 1 if the year is $\mathrm{K}$ and 0 otherwise. 


\subsection{Pearson correlation matrix}

Table 2 sets out the Pearson correlations between the different independent variables as well as their statistical significance ( $\mathrm{P}$ values shown in parentheses). IDP is positively and significantly associated with the BA, SIZE and DEBT (the other correlations are not significant at the $10 \%$ level). In a fairly consistent way, IDT is positively and significantly correlated with BA, DOS, SIZE and DEBT. This shows that ID are positively associated with the Big 4. However, they are positively associated with diffused ownership structure only when they make up at least one third of the boards of directors. As regards the control variables, the results seem to indicate that ID are positively associated with the size of the firm and also its level of debt. Note that despite some statistically significant correlations, the coefficients do not seem high enough to cause problems of multicolinearity.

\subsection{The regression results}

Table 3 presents the pooled OLS regression results of the two different specifications of our empirical model. The first specification uses the IDP variable, the corporate governance variables and the control variables. The second specification replaces the PID variable by IDT and retains all the other variables used.

Our variables of interest are first examined. The first specification shows an adjusted R2 of $12.8 \%$ and a Fisher statistic significant at the $1 \%$ level. PID shows a negative correlation coefficient of -0.017 . This coefficient is significant at the $10 \%$ level. This indicates that the presence of ID is negatively associated with the management of WCDAC. In other words, the presence of these ID tends to attenuate such adjustment, which confirms our first hypothesis. BA also shows a negative coefficient of -0.021 . This coefficient is significant at the $5 \%$ level. This shows that the Big 4 can also play a moderating role as regards the discretionary adjustment of short-term accruals, which is also consistent with our second hypothesis. On the other hand, DOS has a negative coefficient, not significant at the $10 \%$ level. So, it seems that diffused ownership structure has no influence on the management of these accruals. This result tends to disconfirm our third hypothesis. The second specification shows an adjusted R2 of $13 \%$ (i.e. slightly greater than that of the first). This slight increase is induced by the replacement of the PID variable by IDT since all the other variables remain unchanged. The latter variable shows a more substantial and more significant correlation coefficient than that of PID. This result seems entirely logical. ID are more effective in moderating the discretionary adjustment of accruals when they represent at least a third of the members of the boards of directors. This supports the recommendation of the Viénot 1999 report. Moreover, it further confirms the first hypothesis of this research. The coefficients of the BA and DOS variables are, in terms of extent and statistical significance, consistent with those of the first specification. They thus lead to the same conclusions.

As regards the control variables for our two specifications, SIZE has, contrary to our expectations, a positive coefficient, significant at the 5\% level. The larger the company, the more the corporate managers tend to adjust earnings upwards. DEBT has a negative coefficient, significant at the 5\% level. Leverage can, on the basis of this finding, represent a deterrent to the opportunistic management of accounting numbers. These two last results, although not in line with the expectations of the positive accounting theory (Watts and Zimmerman, 1986), are consistent with those found by some previous studies (Chung et al., 2002; Piot and Janin, 2007).

On the other hand, in accordance with our predictions, REP has a positive coefficient, significant at the $1 \%$ level. The poorer the company's relative earnings performance, the more corporate managers manipulate their earnings upwards. Finally, the LWCDAC are negative and significant, which is consistent with the phenomenon of reversibility of discretionary accruals from one period to another (Koh, 2003; Grace and Koh, 2005).

\section{CONCLUSION}

The main reports on corporate governance in France (collective, 2003) emphasize the functioning of boards of directors. Independent directors (ID) constitute one of the decisive sources of the effectiveness of these boards (Beasly, 1996; Fama and Jensen, 1983). As Stolowy and Jeanjean (2006) point out, the financial markets increasingly look to these ID to help guarantee reliable and accurate financial information. The evaluation of the effectiveness of this role is therefore an interesting empirical question. It is from this standpoint that this study has 
aimed to examine the influence of ID and two other corporate governance mechanisms, namely the audit quality and the ownership structure, on earnings management.

Our analysis, conducted over a period of 4 years from 2001 to 2004, was applied to a sample of 239 different non-financial French companies listed on the Paris stock exchange.

The dependent variable of the empirical model is working capital discretionary accruals computed using a cross-sectional intra-industry estimation model. The contribution of this approach in terms of detecting earnings management has been highlighted by several previous papers (Young, 1999; Peasnell et al., 2000; Xie et al., 2003). The ID variable was declined by two measures that are based on information from the annual reports published by the companies in our sample. In France, the retained conception of independence seems largely based on the combined Viénot and Bouton Reports (collective, 2003). This conception tends increasingly to be based upon the main criterion of the absence of any link of direct or indirect interest between the director and the firm. French companies often refer to these reports in mentioning the independence of their directors. Therefore, only the directors described as such in these reports are considered independent. The other independent variables of corporate governance (i.e. the audit quality and the ownership structure) were computed, as in some previous studies, by the presence of a Big 4 and the dispersion of the company's capital.

The findings show that the presence of ID can moderate the management of WCDAC. This role appears to be more effective when these ID make up at least one third of the members of boards of directors, as recommended by the Viénot 1999 report. The Big 4 auditors can also limit this discretionary adjustment. However, no statistically significant relationship was observed between dispersion vs. concentration of ownership structure and WCDAC. This study adds to the limited research into the relationship between corporate governance and earnings management in France. It also gives empirical evidence on the effectiveness of the Viénot 1999 report's recommendations. Thus, it should be of interest to academics as well as regulators in preparing and amending corporate governance laws.

\section{AUTHOR INFORMATION}

Ramzi Benkraiem is a Professor of financial accounting at GSCM - Montpellier Business School, France. His main research interests are corporate governance, corporate financial performance, earnings management and earnings quality.

\section{REFERENCES}

1. Beasley, M. (1996). An empirical analysis of the relation between the board of director composition and financial statement fraud. Accounting Review, 71, 443-65.

2. Benkel, M., Mather P. \& Ramsay A. (2006). The association between corporate governance and earnings management: The role of independent directors. Corporate Ownership and Control, 3, 65-75.

3. Charreaux, G. (2004). Corporate governance theories: from micro theories to national systems theories. Working Paper, University of Bourgogne, from: http://ideas.repec.org/p/dij/wpfarg/1041202.html

4. Chung, R. Firth, M. \& Kim, J.B. (2002). Institutional monitoring and opportunistic earnings management. Journal of Corporate Finance, 8, 29-48.

5. Chung, R. Firth, M. \& Kim, J.B. (2005). Earnings management, surplus free cash flow and external monitoring. Journal of Business Research, 58, 766-76.

6. Collective (2003). Corporate governance in listed companies: Consolidation of Viénot and Bouton reports, AFEP - MEDEF Business Associations [in French].

7. Cormier, D. Magnan, M. \& Morard, B. (1998). Strategic earnings management: Is the Anglo-Saxon model appropriate to the Swiss context? Comptabilité Contrôle Audit; 1, 25-48 [in French].

8. Cormier, D. \& Magnan, M. (1995). Strategic earnings management: the case of forecast-issuing companies during an IPO. Comptabilité Contrôle Audit, 1, 45-61 [in French].

9. Cormier, D. \& Martinez, I. (2006). The association between management earnings forecasts, earnings management and stock market valuation: evidence from French IPO's. The International Journal of Accounting, 4, 209-36. 
10. DeAngelo, L. (1981). Auditor size and audit quality. Journal of Accounting and Economics, 3, 183-99.

11. Dechow, P.M. \& Dichev, I.D. (2002). The quality of accruals and earnings: the role of accrual estimation error. The Accounting Review, 77, 35-59.

12. Dechow, P.M. \& Skinner, D.J. (2000). Earnings management reconciling the views of accounting academics, practitioners and regulators. Accounting Horizons, 14, 235-50.

13. Degeorge, F. Patel, J. \& Zeckhauzer, R. (1999). Earnings management to exceed thresholds. Journal of Business, 72, 1-35.

14. Fama, E. \& Jensen, M. (1983). Separation of ownership and control. Journal of Law and Economics, 26, $301-26$.

15. Fama, E. (1981). Agency problems and the theory of the firm. Journal of Political Economy, 88, 288-297.

16. Francis, J.R. \& Krishnan, J. (1999). Accounting accruals and auditor conservatism. Contemporary Accounting Research, 16, 135-65.

17. Grace, C.H. \& Koh, P.S. (2005). Does the presence of institutional investors influence accruals management? Evidence from Australia. Corporate Governance, 13, 809-23.

18. Healy, P. (1985). The effect of bonus schemes on accounting decisions. Journal of Accounting and Economics, 7, 85-107.

19. Jeanjean, T. (2001). Contribution to the analysis of earnings management in French listed companies. (Paper presented at the Congress of the Francophone Accounting Association [in French]).

20. Kim, J.B. Chung, R. \& Firth, M. (2003). Auditor conservatism, asymmetric monitoring and earnings management. Contemporary Accounting Research, 20, 323-59.

21. Klein, A. (2002). Audit committee, board of director characteristics, and earnings management. Journal of Accounting and Economics, 33, 375-400.

22. Koh, P.S. (2003). On the association between institutional ownership and aggressive corporate earnings management. The British Accounting Review, 35, 105-28.

23. Peasnell, K.V. Pope, P.F. \& Young S. (2000). Accrual management to meet earnings targets: UK evidence pre- and post-Cadbury. The British Accounting Review, 32, 415-45.

24. Petra, S.T. (2007). The effect of corporate governance on the informativeness of earnings. Business and Economics, 8, 129-152.

25. Piot, C. \& Janin, R. (2007). Audit quality, corporate governance and earnings management in France. European Accounting Review, 16, 429-54.

26. Sloan, R.G. (1996). Do stock prices fully reflect information in accruals and cash flows about future earnings? The Accounting Review, 71, 289-315.

27. Stolowy, H. \& Breton, G. (2004). Accounts manipulation: a literature review. The Review of Accounting and Finance, 3, 5-66.

28. Stolowy, H. \& Jeanjean, T. (2006). The financial competence of boards of directors. (Paper presented at the Congress of the Francophone Accounting Association [in French]).

29. Watts, R. \& Zimmerman, J. (1986). Positive accounting theory. (Prentice-Hall, New Jersey).

30. Xie, B. Davidson, W.N. \& DaDalt P.J. (2003). Earnings management and corporate governance: the role of the board and the audit committee. Journal of Corporate Finance, 9, 295-316.

31. Young, S. (1999). Systematic measurement error in the estimation of discretionary accruals: an evaluation of alternative modeling procedures. Journal of Business Finance and Accounting, 26, 833-62. 